\title{
ДО 80-РІЧЧЯ ВИДАТНОГО ВЧЕНОГО, ПЕДАГОГА ТА ГРОМАДСЬКОГО ДІЯЧА IВАНА АНТОНОВИЧА МАЗУРА
}

Іван Антонович Мазур народився 20 січня 1938 року в селі Гвардійське на Хмельниччині.

Після закінчення школи дорога Івана Мазура пролягла до Одеського фрармацевтичного інституту, який в 1959 році перевели до Запоріжжя. Через рік саме тут, у Запоріжжі, він отримав диплом. Закінчивши навчання з відзнакою, І. А. Мазур вирішив пов'язати свою долю з науковим пошуком і створенням лікарських препаратів. Він залишився працювати у рідному виші, де й пройшов шлях від асистента до завідувача кафредри фрармацевтичної хімії.

Під керівництвом профресора І. А. Мазура відбувалося становлення та розбудова кафедри фрармацевтичної хімії Запорізького державного медичного університету. Завдяки його професійним та організаторським здібностям кафедра стала фрлагманом вітчизняної вищої освіти із підготовки висококваліфікованих фрахівців для фрармацевтичної галузі, а її наукова діяльність зосереджується на досягненні головної мети - розробці нових, оригінальних, високоесрективних та конкурентоспроможних лікарських засобів.

Вражає титанічна праця колективу кафредри на ниві пошуку нових біологічно активних речовин. Під керівництвом профресора І. А. Мазура розроблені та апробовані методики синтезу понад двадцяти класів органічних речовин. Уперше вивчено аномальний перебіг ряду хімічних реакцій органічного синтезу, що має як теоретичну цінність, так і значне прикладне значення для фрормування нових напрямків синтетичних досліджень. Синтезовано понад дві тисячі нових, раніше не описаних у літературі хімічних сполук гетероциклічної будови, які $€$ носіями різноманітних видів біологічної активності.

У 80-ті роки XX століття наукова інтуїція професоpa І. А. Мазура підказала доцільність поглибленого вивчення властивостей речовини із лабораторним шифром E-8252 (у подальшому - Тіотриазолін). У 1993 році Фармакологічний комітет України дозволив проведення першої та другої фраз клінічних випробувань препарату. У 1994 році результатом наполегливої праці став дозвіл на клінічне використання «Тіотриазоліну» - першого оригінального українського лікарського засобу. Цей препарат широко застосову- ють у медичній практиці і фрахівці розширюють можливості його застосування у кардіології, неврології, офртальмології, гінекології, травматології, імунології, а також у педіатрії. Лікарі переконалися у дієвості Тіотриазоліну в терапії хворих на інфраркт міокарда, недостатність мозкового кровообігу, хронічний гепатит, ниркові патології, травми та опікові ураження очного яблука, трофрічні виразки, кишкові ерозії, ерозії шийки матки тощо. Зараз орармацевтична промисловість України випускає розроблені під керівництвом Івана Антоновича Мазура 1,0 і 2,5 \% розчини тіотриазоліну для ін'єкцій, очні краплі, мазь та супозиторії з тіотриазоліном, а також комплексні препарати на основі тіотриазоліну («Тіоцетам», «Тіоцетам фрорте», «Тіодарон», «Індотрил»). Вагомим здобутком у сорері забезпечення якості вітчизняних ліків є включення до Державної Фармакопеї України монографії на субстанцію «Морфолінію тіазотат» (тіотриазолін), а також її лікарські форми (таблетки, розчин для ін'єкцій).

Профресор Іван Мазур є членом редакційних колегій багатьох наукових видань. Саме він стояв біля витоків заснування у ЗДМУ фрахового наукового журналу «Актуальні питання фрармацевтичної та медичної науки та практики» та був його першим головним редактором. Чималих зусиль доклав Іван Антонович для відкриття у ЗДМУ спеціалізованої вченої ради із захисту дисертацій на здобуття наукового ступеня доктора та кандидата фрармацевтичних наук, тривалий час був її головою. Профресор І. А. Мазур - фрундатор Фармацевтичної асоціації України та їі регіонального Запорізького осередку. Він брав активну участь у створенні Державної Фармакопеї України, а також галузевих стандартів вищої фрармацевтичної освіти. Така активна діяльність та небайдужість профресора Івана Мазура відзначена низкою почесних титулів і звань - він є заслуженим діячем науки і техніки, академіком АНТК України, відмінником охорони здоров'я, заслуженим винахідником, довічним стипендіатом Президента України, лауреатом Премії Кабінету Міністрів України, а також володарем медалі «За розвиток Запорізького краю».

Важливо, що Іван Антонович не зупиняється на досягнутому, а бере активну участь у розробці нових оригінальних вітчизняних лікарських засобів та ство-

ISSN 2312-0967. Pharmaceutical review. 2018. № 1 
Ювілеї

\section{Jubilees}

ренні фріксованих комбінацій ліків. На різних стадіях впровадження перебувають препарати під запатентованими назвами «Кардіотрил», «Гіпертрил», «Ангіолін», «Тіотриазид», «Карботрил» та «Аргітрил».

За результатами такої плідної роботи отримано понад 300 патентів України, які захищають наукові розробки від несанкціонованого використання і, звісно ж, підтверджують їх новизну. Розроблені на кафедрі лікарські засоби запатентовані та використовуються за кордоном (Росія, Білорусь, Молдова, Грузія, Азербайджан, Казахстан, Узбекистан, Таджикистан, Китай, Корея). Для узагальнення досвіду використання в медицині лікарських засобів, створених за участі співробітників кафедри фрармацевтичної хімії ЗДМУ, а також для окреслення подальших перспектив розвитку за ініціативи професора І. А. Мазура було проведено три Міжнародних науково-практичних конференції та видано понад двадцять монограсрій.

Профресор І. А. Мазур зробив значний внесок у формування науково-педагогічного потенціалу ЗДМУ - він підготував 32 кандидати та 12 докторів наук.
Іван Антонович приділяє значну увагу навчальнометодичній роботі, він $є$ блискучим лектором. Під його керівництвом було розроблено належне методичне забезпечення для вивчення всіх дисциплін кафредри фрармацевтичної хімії ЗДМУ за принципами Європейської кредитно-трансорерної системи організації навчального процесу. Просресор І. А. Мазур брав активну участь у створенні дев'яти навчальнометодичних посібників, які одержали грифи Міністерства освіти та науки, а також Міністерства охорони здоров'я України.

Досягнення профресора І. А. Мазура в науці, педагогічній та громадській діяльності - приклад для нових поколіннь студентів, працівників практичної фрармації та науковців.

Колектив кафредри фрармацевтичної хімії Запорізького державного медичного університету, редакційна рада журналу «Фармацевтичний часопис», фрармацевтична спільнота, друзі та колеги щиро вітають ювіляра та бажають йому міцного здоров'я, родинного щастя, добробуту, благополуччя, життєвого оптимізму, нових звершень та творчої наснаги! 